DOI: $10.1515 / \mathrm{rpp}-2017-0061$

Postgraduate Student, MARINA PAVLENKO

Khmelnytskyi National University

Address: 11 Instytutska St., Khmelnytskyi, 29016, Ukraine E-mail: marinapavlenko2398@gmail.com

\title{
THE PROBLEM OF DEVELOPING PROFESSIONAL MOBILITY OF TEACHERS IN THE WORKS OF FOREIGN SCHOLARS
}

\begin{abstract}
The article analyzes the positions of foreign and domestic scholars on the problem of developing professional mobility of teachers. It has been stated that today professional mobility is a necessary component of training a skilled worker. It has been indicated that the teacher possesses an appropriate set of competences that provide an opportunity to be flexible, quickly orientate in the profession, to be competitive in the labor market, ready for further training, retraining and self-education. It has been specified that the factors that actualize these requirements are innovative processes in society; rapid aging of knowledge; the dependence of success in life on the level of education and profession; dynamism and rapid changes in the labor market requirements; the emergence of new professions and the disappearance of the obsolete ones. It has been justified that professional mobility is a complex, integrative, multifactorial entity. Professional mobility provides human development through the formation of key, general professional competencies; human activity, determined by events that change the environment (the result of the activity is self-realization of an individual both in the profession and in everyday life), the process of transformation by people not only themselves, but also their professional-life environment. It has been pointed out that mobility in the pedagogical sphere is determined by objective factors as well as in material production, its direction and intensity depends more on personal, subjective factors. The society is interested in such a specialist who is able to think independently and solve various problems, apply the knowledge gained in the learning process; possesses critical and creative thinking, formed in the process of education; knows how to acquire new knowledge, is capable of self-learning, self-education. It has been concluded that the perspectives for further researchers are seen in studying the problem of developing professional mobility of teachers in European experience.
\end{abstract} teacher.

Keywords: mobility, professional mobility, development of professional mobility,

\section{INTRODUCTION}

One of the most characteristic features of the current stage of the society development is the growing intensity and dynamism of various-scale and multidirectional changes that globally cover all spheres and processes of people's life activity. The processes of globalization and integration necessitate the constant need to be ready to move in the social space, easily adapt to changing conditions and flexibly interact with different cultural and social systems and actors. Intensive development and renewal of techniques and technology continuously change the quality and conditions of professional activity, forcing the employee throughout the working life to continuously learn new methods and activities in the profession, improve the level of skills and education, change the place of 
work and even the profession. The volume and complexity of information that a modern person has to learn in all spheres of their life comprises social, economic, professional, everyday aspects. This requires people to quickly update their knowledge, flexibly orienting themselves in the continuous changes in the information environment. In other words, in order to be successful and competitive, a specialist is to possess certain personal qualities to be flexible, mobile, ready for any changes, to be able to adapt quickly and effectively to new conditions.

\section{THE AIM OF THE STUDY}

The aim of the study is to carry out a theoretical analysis of the conceptual positions of foreign scholars on the problem of developing teachers' professional mobility.

\section{THEORETICAL FRAMEWORK AND RESEARCH METHODS}

Empirical study of mobility processes began in the countries of Europe (Great Britain, Sweden) from the middle of the twentieth century. But it becomes known from the work of American researchers how to conduct research, what concepts to use, what statistics to attract for the processing of empirical information (R. Bendix, P. Blau, A. Danken, D. Freserman, R. Hauser, S. Lipset).

Attention to professional mobility has become the subject of research by scientists of different industries in the 70s of the twentieth century. Various aspects of mobility were studied by sociologists and philosophers (C. Davis, V. Duncan, E. Durkheim, S. Lipset, P. Sorokin, M. Weber), economists (V. Daniuk, K. Marx, A. Stakhov), psychologists (A. Leontiev, A. Markova, S. Rubinstein, D. Uznadze, G. Weiser et al.).

The first scientists who spoke about professional mobility as an integral part of public life were B. Barber, E. Hiddens, P. Sorokin, J. Wenig. Also the problem of developing professional mobility of teachers to quickly and efficiently self-organize, change in accordance with life and professional needs, adapt to a certain professional environment and professional groups and, finally, effectively work, can be found in the writings of various scholars (B. Ihoshev, R. Prima, L. Sushentseva, I. Shpektorenko).

The research has been conducted with the use of gathering, analyzing and systematizing relevant information.

\section{RESULTS}

Integration of the national education system into the European educational space thus requires the involvement of teachers in the in-depth study, analysis and use of foreign educational innovations. Therefore, the issue of providing a European level of quality to increase the professional mobility of the teacher remains relevant for both domestic and foreign researchers.

Mobility, from the point of view of the Czech sociologist N. Formanek, is a special concept and method within the framework of sociology theory and methods that explores "the mass movements of individuals (layers, groups) arising from movement, change, development of the social class structure" (Olesnevich, Vovkanich, \& Zlupko, 1981, p. 10).

The term "mobility" means flexibility, a willingness to quickly complete a task. It was introduced into scientific circulation by sociologists to determine the phenomena that characterize the movements of social groups and individuals in the social structure of society (social mobility). A deep study of this phenomenon from the standpoint of philosophy, sociology, economics, demography allowed us to differentiate the concept of mobility by finding out what it is: vertical and horizontal, individual and group, intergenerational and intergenerational; social, labor, cultural, interprofessional, professional and other types of mobility. In our opinion, such a differentiation of the scientific concepts of mobility 
associated with strengthening the dynamism of social processes at the present stage of the development of society inevitably leads to an increase in the mobility of people in the most diverse "vectors" of their social functioning (Bilyk, 2009).

Another famous educator I. Pestalozzi (1989) defined mobility as flexible adaptability and placed it on a par with such qualities as obedience and malleable modesty, which he considered to be the most important knowledge that should be given to a person. "Flexible adaptability, preparedness for various kinds of labor will be the advantages of a person over the more wealthy ones when earning a living," I. Pestalozzi (1989) asserted. Since one of the most important determinants of people social development is their basic activity, self-realization in activities that bring pleasure, which provides social comfort, contributes to the fullest development of man. In order to successfully implement in their professional activities, people must have professional flexibility, which is achieved "through the development of mental abilities and increases due to the development of moral consciousness" (p. 313).

C. Lipset \& R. Bendix (1959) understand by the concept of mobility the movement of a group of specialists engaged primarily in mental work (pp. 6-13).

Thus, Karl Marx in his time subjected to a careful analysis the very process of labor, defined its vital role in the activity of the individual and society, as well as its direct relationship to the process of forming professional mobility of specialists. He wrote that "the division of labor within modern society is characterized by the fact that it generates specialties, isolated professions" (Kuzmina, 1980, p. 159).

The first provisions on professional mobility as an integral part of public life are set forth in the works of B. Barber (1957), E. Hiddens, P. Sorokin (1992). The works by such scholars as I. Janzhul, B. Mitin, I. Vyshnegradskyi I. Janzhul et al. are devoted to the historical aspect of the emergence of the problem of professional mobility in science and education.

Active consideration of this problem in professional pedagogy started in the seventies of the twentieth century. Professional mobility at that time was defined primarily as the willingness of the worker, including the civil servant, to rapidly change production tasks, jobs and even specialties within the same profession or industry, the ability to quickly master new specialties or changes in them that arise under the influence of technical transformations (Shpektorenko, 2007, pp. 467-472).

The study of the dictionary literature showed that the concept of "professional mobility" is sufficiently capacious and ambiguous in its interpretation. Moreover, it has a rather complex structure. Thus, professional mobility is defined in a large psychological vocabulary as "the ability and readiness of an individual to quickly and successfully master new techniques and technology, acquire the missing knowledge and skills, which ensures the effectiveness of preparation for new professional activity" (Meshcheryakov, \& Zinchenko, 2003, p. 24].

For researchers of professional mobility, Pitirim Sorokin's classic social work "Social Mobility", which was published in New York in 1927, but undoubtfully laid the foundations for the original direction of research on problems of stratification and mobility has for many decades remained classics. It should be noted that P. Sorokin defines mobility as a transition, the movement of a social object (individuals, groups, values) from one position to another within the social space. The scientist distinguishes two basic types of mobility: horizontal and vertical. Horizontal mobility is the transition of an individual or social object from one social position to another, which is at the same level (social stratum), as well as territorial movement (change of residence place). Vertical mobility is the 
transition of an individual or social object from one social stratum to another, a change in social status (a new position in society) (Sorokin, 1992).

The ideas of P. Sorokin were developed by American sociologists S. Lipset and R. Bendix (1959). The study of professional mobility in its various aspects is widely represented in the classic works of Western sociologists. Scientists noted that mobility is necessary to ensure the stability of modern society, since open access to elite positions helps capable and ambitious people to climb the social ladder (Horodianenko, 2008, 342).

The works of the British author D. Goldthorpe, the German sociologist B. Wegener, the researchers from Netherland V. Ulti and R. Luüks, and from the Denmark I. Sorensen are distinguished by the development of sociocultural aspects of the phenomenon of professional mobility. The theory they propose puts forward two important factors of stratification and mobility: the sociocultural paradigm of society and the political system. In their writings, scientists view socio-cultural mobility as a set of elements of the inner life of social actors, integrated into an integral system that provides the degree of subjective mobility that is necessary for adaptation to the environment or for an active impact on it (Goldthorpe, 1977).

Empirical research, conducted in America and Europe in the middle of the twentieth century, showed the determining role of professional achievements for the process of social mobility. In this regard, there is a need to define the concept of "professional mobility", which appeared in the scientific literature since the early 1950s. At first it was interpreted as a change of various types of occupations or professions related to the main types of labor: physical, non-physical and farm. Thanks to the works of American sociologists S. Lipset and R. Bendix (1959), professional mobility has been given the status of an independent subject of research. The concept they proposed was one of the attempts to develop a theoretical model of directly professional mobility. Concerning professional mobility, scientists believed that its essence can be revealed on the basis of such empirical indicators: - the movement of the generation of "children" along the line "physical labor nonphysical labor - farm labor" in comparison with the generation of "fathers"; evaluation of the inheritance of prestigious and non-prestigious occupations (prestigious occupations are defined as related to nonphysical work, and non-prestigious ones are related with physical and farm work) - determination of the intensity of ascending, descending and general vertical mobility (Lipset, \& Bendix, 1959).

A significant contribution to the development of the theoretical foundations for the formation of professional competence as a basis for the development of mobility of future specialists in the context of the continuity of higher education was provided by the works of domestic and foreign scientists (R. Dave, E. Durkheim, N. Nychkalo et al.).

The study of the problem of professional mobility formation goes with its roots to the study of the phenomena of the division of labor and social displacements. According to E. Durkheim (1996), the division of labor is the main factor of social progress. The individualization of social behavior associated with the intensification of the division of labor, mentioned by E. Durkheim, was reflected in the concept of "plasticity", which he introduced for assessment of the relations change in the "man-labor" system. This concept reflects the capability and possibility of an individual to form his labour, his professional orientations and prospects. A characteristic feature of "plastic" worker is the constant internally determined increase in the level of self-competitiveness, identification of new opportunities for his profession and new forms of professional self-actualization. 
A qualitative study of attitudes, motives and values in the process of professional mobility is found in the writings by P. M. Hodge, N. Toumi, D. Treiman and other American and European authors (Hodge, 1963; Treiman, 1977).

The definition of "professional mobility" traditionally includes the ability of a specialist to change a profession, a place and a kind of activity. At the same time, the dynamics of modern social life is making its own adjustments to the understanding of this concept, without restricting professional mobility within the framework of one industry, and considering the mobility of a specialist as an opportunity for professional and personal self-realization in any sphere of socio-economic and sociocultural activity. A future specialist can master such willingness in the higher education system, which is also inherent in mobility, variability and democracy.

In the works of foreign scholars Sh. Fitzpatrick, H. Goon, the relationship between education, career and social mobility of a young specialist is shown. A significant contribution to the development of the theoretical foundations for forming professional competence as a basis for the development of future specialists' mobility in the context of the continuity of higher education was made by the works of domestic and foreign scholars such as R. Dave, S. Honcharenko, N. Nychkalo et al.

The concept of the professional mobility of a specialist in a market economy in a purely economic context is described in the scientific studies of domestic scholars (L. Danylova, N. Nychkalo, A. Symonchuk) and foreign scientists (P. Blau, A. Filatov, G. Mukhamedzyanov, A. Oleinikova). The works by K. Barbakova, V. Kugel, I. Martyniuk, V. Osovski, A. Shkaratan, V. Yadov and others were dedicated to the problem of studying certain aspects of the concept of professional mobility and its formation.

The analysis of scientific research on the problem of professionalization of specialists in the context of professional mobility development in them shows that there are not so many of them, but the popularity of this problem has recently increased.

It is necessary to emphasize the scientific potential of E. Sayfutdinova in the latest years. Considering professional mobility as a change in the position of a person on the labor market and as a kind of social mobility E. Sayfutdinova (1997) suggests the following types of professional mobility:

- initial mobility (choice of the profile of education);

- by the activity of participation of the individual in it: active (the person on his own initiative is looking for a new job) and passive (as a result of the loss of the workplace on the initiative of the employer);

- in terms of variability - professional mobility without change and with a change in the profile of work;

- by primariness (secondariness): primary professional mobility (change of main place of work) and secondary (change of second job) (Sayfutdinova, 1997).

We consider the professional mobility of teachers as the realization of his professional activity oriented to obtaining a dual result - the high quality of the activity itself (the training of a professionally mobile skilled worker) and positive changes in themself. The principle of creative initiative, designed to develop in the individual independence, creativity and initiative, was developed by S. Rubinstein (1986), who said that "the subject is not only revealed and manifested in his deeds, in acts of his creative initiative; he is himself created and determined in them. Therefore, one can determine what he is by what he does; the direction of his activity can be determined and formed by oneself." (p. 107). 
Professional mobility of the teacher can be considered as internal freedom, personal self-improvement based on stable values and the need for self-organization, selfdetermination and self-development, the ability to respond quickly to changes in society through literacy, education and professional competence. According to E. Zeer (2006), it can provide vocational education with "convertible", social-professional mobility.

Studies of both domestic (S. Kugel, R. Ryvkina et al.) and foreign (T. Ordern, E. Yezh, Yu. Wenig) scholars show that mobility in the pedagogical sphere has a number of characteristics, arising from the specifics of professional activity. First of all, in education, the correlation of stability and mobility of personnel is different than in material production: ensuring the flexibility and multifunctionality of vocational education in accordance with the needs of society increases the "specific weight", the importance of mobility.

Secondly, the mobility in the pedagogical sphere is determined by objective factors as well as in material production, its direction and intensity depends more on personal, subjective factors. The society is interested in such a specialist who is able to think independently and solve various problems, apply the knowledge gained in the learning process; possesses critical and creative thinking, formed in the process of education; knows how to acquire new knowledge, is capable of self-learning, self-education.

\section{CONCLUSIONS}

Today, professional mobility is a necessary component of training a skilled worker. It presupposes that the teacher possesses an appropriate set of competences that provide an opportunity to be flexible, quickly orientate in the profession, to be competitive in the labor market, ready for further training, retraining and self-education. The factors that actualize these requirements are innovative processes in society; rapid aging of knowledge; the dependence of success in life on the level of education and profession; dynamism and rapid changes in the labor market requirements; the emergence of new professions and the disappearance of the obsolete ones.

Professional mobility is a complex, integrative, multifactorial entity. Professional mobility provides human development through the formation of key, general professional competencies; human activity, determined by events that change the environment (the result of the activity is self-realization of an individual both in the profession and in everyday life), the process of transformation by people not only themselves, but also their professional-life environment.

The perspectives for further researchers are seen in studying the problem of developing professional mobility of teachers in European experience.

\section{REFERENCES}

1. Barber, B. (1957). Social stratification. Harcourt: Brace.

2. Bilyk, O. (2009). Osnovni napriami zberezhennia i rozvytku natsionalnoho liudskoho kapitalu za rakhunok aktyvizatsii trudovoi mobilnosti. Ukraina: aspekty pratsi, 1, 43-46.

3. Diurkgeim, E. (1996). O razdelenii obshchestvennogo truda. Metod sotsiologii. Moskva: Kanon.

4. Goldthrope, J. H., \& Lewellyn, C. (1977). Class mobility and kinship. Oxford: Nuffield college.

5. Hodge, R. W. (1963). Educational and occupational mobility. The American journal of sociology, 685 (3), 629-644. 
6. Horodianenko, V. H. (2008). Sotsialna entsiklopediia. Kyiv: Akademvidav.

7. Lipset, S., \& Bendix, R. (1959). Social mobility in industrial society. Berkeley and Los Angeles: University of California Press.

8. Kuzmina, N. V. (1980). Sistemnyy podkhod V pedagogicheskikh issledovaniyakh. Metodologiya pedagogicheskikh issledovaniy, 82-117.

9. Meshcheryakov, B. G. \& Zinchenko, V. P. (2003). Bolshoy psikhologicheskiy slovar. Moskva: Praym-Yevroznak.

10. Olesnevich, L. A., Vovkanich, S. I., \& Zlupko, S. N. (1981). Mobilnost kadrov na promyshlennom predpriyatii. Kyiv: Naukova dumka.

11. Rubinshteyn, S. L. (1986). Printsip tvorcheskoy samodeyatelnosti (k filosofskim osnovam sovremennoy pedagogiki). Voprosy psikhologii, 4, pp. 101-109.

12. Pestalotstsi, Y. G. (1989). Pedagogicheskoe nasledie. Moskva: Pedagogika.

13. Sayfutdinova, Ye. (1997). K voprosam o professionalnoy mobilnosti u molodezhi v usloviyakh stanovleniya rynochnykh otnosheniy. Sovremennoe sostoyanie $i$ perspektivy razvitiya gumanitarnykh nauk, II, 38-42.

14. Shpektorenko, I. (2007). Poniattya ta struktura fenomenu profesiinoi mobilnosti derzhavnoho sluzhbovtsia. Universitetski naukovi zapiski, 4 (24), 467-472.

15. Sorokin, P. A. (1992). Chelovek. Tsivilizatsiya. Obshchestvo. Moskva: Izdatelstvo politicheskoi literatury.

16. Treiman, D. (1977). Occupational prestige in comparative perspective. New York: Academic press.

17. Zeer, E. F. (2006). Psikhologiya professionalnogo razvitiya. Moskva: Akademiya. 